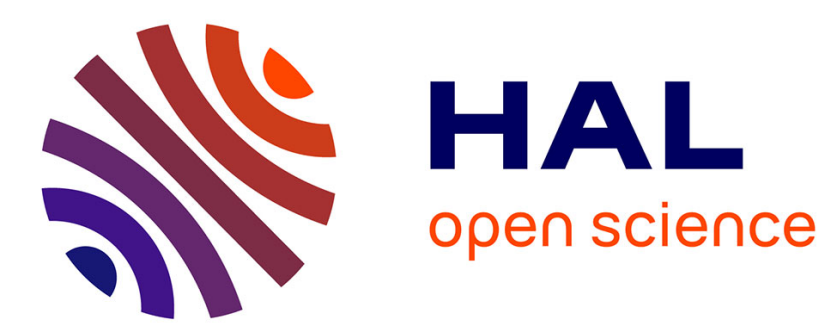

\title{
Répertoire des textes législatifs et réglementaires publiés pendant le mois d'octobre 1999
}

- [.]revue Forestière Française, Rédaction

\section{- To cite this version:}

- [.]revue Forestière Française, Rédaction. Répertoire des textes législatifs et réglementaires publiés pendant le mois d'octobre 1999. 1999, pp.645. 10.4267/2042/5473 . hal-03534924

\section{HAL Id: hal-03534924 \\ https://hal.science/hal-03534924}

Submitted on 19 Jan 2022

HAL is a multi-disciplinary open access archive for the deposit and dissemination of scientific research documents, whether they are published or not. The documents may come from teaching and research institutions in France or abroad, or from public or private research centers.
L'archive ouverte pluridisciplinaire HAL, est destinée au dépôt et à la diffusion de documents scientifiques de niveau recherche, publiés ou non, émanant des établissements d'enseignement et de recherche français ou étrangers, des laboratoires publics ou privés. 


\section{législation et \\ jurisprudence}

\section{RÉPERTOİRE DES TEXTES LÉGISLATIFS ET RÉGLEMENTAIRES PUBLIÉS PENDANT LE MOIS D’OCTOBRE 1999}

\section{ENVIRONNEMENT}

\section{- Décret}

Décret du $1^{\mathrm{er}}$ octobre 1999 portant classement du parc naturel régional des Causses du Quercy (région Midi-Pyrénées).

(J.O. Lois et Décrets, vol. 131, $n^{\circ} 231$, 4-5 octobre 1999, pp. 14747-14748)

Concerne le département du Lot.
FONDS FORESTIER NATIONAL

REBOISEMENT — PLANTS FORESTIERS

\section{- Arrêté}

Arrêté du 30 septembre 1999 portant réglementation de la récolte et de la commercialisation de matériels forestiers de reproduction du Frêne commun.

(J.O. Lois et Décrets, vol. 131, $\mathrm{n}^{\circ} 253$, 30 octobre 1999, pp. 16305-16306)

Modifications des arrêtés de juin 1973 et novembre 1991. 